\title{
Effects of Repetitive Exposure to Pain and Morphine Treatment on the Neonatal Rat Brain
}

\author{
Lasse Dührsen $^{a, c}$ Sinno H.P. Simons ${ }^{a, e, f} \quad$ Mark Dzietko $^{a, g} \quad$ Kerstin Genz $^{a}$ \\ Ivo Bendix ${ }^{d}$ Vinzenz Boos ${ }^{a}$ Marco Sifringer $^{a}$, b Dick Tibboel $^{e}$ \\ Ursula Felderhoff-Mueser ${ }^{d}$
}

\begin{abstract}
Departments of a Neonatology and ${ }^{\mathrm{b}}$ Anaesthesiology and Intensive Care Medicine, Charité-Universitätsmedizin Berlin, Berlin, 'Department of Neurosurgery, Universitätsklinikum Hamburg-Eppendorf, Hamburg, and

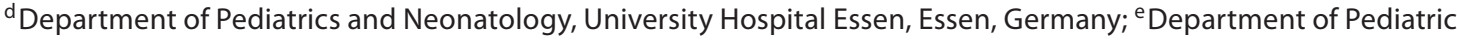
Surgery and Pain Expertise Centre, and ${ }^{\mathrm{f}}$ Division of Neonatology, Department of Pediatrics, Erasmus MC-Sophia Children's Hospital, Rotterdam, The Netherlands; ${ }^{9}$ Department of Pediatrics, University of California San Francisco, San Francisco, Calif., USA
\end{abstract}

\section{Key Words}

Pain - Morphine - Analgesia $\cdot$ Neurodegeneration .

Rodent study

\begin{abstract}
Background: Untreated exposure to pain in preterm neonates might damage the vulnerable premature brain and alter development. Pain treatment is limited because analgesic agents may also have adverse neurodevelopmental consequences in newborns. Objective: To study the effects of neonatal pain and morphine treatment on the developing brain in a neonatal rat model. Methods: Newborn rats were randomly assigned to: treatment with formalin injections (group 1), saline injections (group 2) and controls receiving no injections (group 3). Treatment was given on postnatal days 1-3 (model A), 1-5 (model B) and 10-12 (model C). Brains were studied histologically and protein expression was evaluated (protein kinase $C$ epsilon and doublecortin). Effects of preemptive morphine treatment were studied in the same
\end{abstract}

models (models $\mathrm{A}+\mathrm{M}$ and $\mathrm{B}+\mathrm{M}$ ). Results: Formalin injections resulted in increased apoptotic scores in models A and B. Saline injections increased the number of degenerative cells only in model B. Morphine showed protective effects in formalin-treated animals of model $\mathrm{A}+\mathrm{M}$ and saline-treated animals of model $B+M$ only. In model $C$, no neurodegenerative effects were detected. The protein expression of doublecortin showed a pain-related upregulation in the thalamus region, whereas protein kinase $C$ epsilon expression was upregulated in the cortex. Conclusions: Severe inflammatory pain and pain caused by repetitive injections in neonatal rats may cause major changes in the developing brain during the first week of life. Morphine may only protect the newborn brain against these changes in specific situations.

Copyright $\odot 2012$ S. Karger AG, Basel

Lasse Dührsen and Sinno H.P. Simons contributed equally to this work.

\section{KARGER}

Fax +41613061234 E-Mail karger@karger.ch www.karger.com
(C) 2012 S. Karger AG, Basel

$1661-7800 / 13 / 1031-0035 \$ 38.00 / 0$

Accessible online at:

www.karger.com/neo
Sinno H.P. Simons, MD, PhD

Division of Neonatology, Department of Pediatrics

Erasmus MC-Sophia Children's Hospital

PO Box 2060, NL-3000 CB Rotterdam (The Netherlands)

Tel. +31 10704 0704, E-Mail s.simons@erasmusmc.nl 


\section{Introduction}

Neonatal intensive care treatment is associated with frequent and intense moments of distress due to ventilatory support and frequent painful procedures $[1,2]$. The developing brain of preterm newborns is very vulnerable and can be harmed by various environmental factors and stressors during a sensitive time of development $[3,4]$. Repetitive, untreated pain and distress may harm the premature brain and have short and long-term effects [5-7]. Although adequate analgesia might prevent effects of pain in these vulnerable patients, the use of analgesics is still under debate $[1,8]$. Clinical trials have not provided sufficient evidence for routine use of morphine in premature neonates [9-11] and rodent studies have shown widespread apoptotic neurodegeneration in the first week of life after administration of many substances with $\mathrm{GABA}_{\mathrm{A}}$-enhancing and/or NMDA receptor-blocking properties $[8,12]$.

Both neuroprotective and destructive roles of morphine have been suggested in adults. Apoptotic cell death of neuronal and glial cells was found only after high doses and prolonged use of morphine [13]. Both neonatal prolonged morphine treatment and repetitive inflammatory pain lead to behavioral changes and abnormal learning in adult rats, while these effects are reduced when pain and morphine treatment are combined $[14,15]$. Preemptive morphine attenuates increased hot plate thresholds, reduced place preference conditioning and reduced ethanol preferences in long-term behavioral rodent studies after neonatal pain exposure $[14,16]$. Interacting effects of hippocampal gene expression are found after the combination of stress and morphine exposure in neonatal mice [17].

The hypothesis of the current study is that exposure to pain results in degeneration of cells in the neonatal rat brain and that preemptive treatment of these animals with morphine protects their brain. The negative effects of pain are hypothesized to be absent in older animals. The effects of pain and preemptive morphine on the brain of newborn and more mature rats were histologically evaluated.

In addition, expression of two important molecular markers, protein kinase $\mathrm{C}$ epsilon (PKCvarepsilon) and doublecortin (DCX), was studied in neonatal rat brains. PKC contributes to stabilization of synaptic connections [18]. DCX is necessary for regular neuronal migration and differentiation in the cerebral cortex [19].

\section{Methods}

Outcome

The primary outcome of this study is the effect of pain, morphine and their combination on neurodegeneration measured as the number of apoptotic cells. Furthermore, the protein expression of PKCvarepsilon and DCX in different brain regions after formalin and saline injections was studied by Western blotting.

\section{Experimental Animal Model}

One-day-old Wistar rat pups (Tierexperimentelle Einrichtungen der Charité-Universitätsmedizin Berlin, Berlin, Germany) were used for these studies. Newborn rats from several litters were randomly assigned to different treatment groups. All experiments were performed in accordance with the German Animal Welfare Act and the guidelines of the Charité-Universitätsmedizin Berlin, and were approved by the local animal protection authority in Berlin (Landesamt für Gesundheit und Soziales, Berlin, Germany). The experiments adhered to the guidelines of the committee for Research and Ethical Issues of the IASP.

In order to investigate age dependency of painful stimuli, 3 different time points with corresponding experimental models were investigated (table 1).

Newborn rats were randomly assigned to injections of $5 \mu \mathrm{l}$ of $10 \%$ formalin in all 4 paws (group 1, severe pain), injections with $5 \mu \mathrm{l}$ of $0.9 \%$ sodium chloride (saline) in all 4 paws (group 2, mild pain) and compared to controls receiving no injections at all (group 3).

Injections were given either from postnatal day 1 to day 3 (P1P3; model A) or from day 1 until day 5 (P1-P5; model B). A third group of animals received injections at days P10, P11 and P12 (model C). Animals used for molecular studies received a single injection on P3. The rat pups were sacrificed on day P4, P6 or P13, respectively. Apart from these treatments, animals from all groups received equal care (i.e. daily handling, separation from the mother, etc.).

\section{Analgesic Treatment with Morphine}

To evaluate the effects of analgesic therapy on pain-induced neuronal degeneration, the preemptive effect of morphine was investigated. Animals received morphine sulfate subcutaneously (500 $\mu \mathrm{g} / \mathrm{kg}, 0.05 \mathrm{mg}$ morphine $/ \mathrm{ml}$ solution) $30 \mathrm{~min}$ before formalin or saline injections. To evaluate the neurotoxic effects of morphine itself, a control group was included that received only subcutaneous morphine on consecutive postnatal days (models $\mathrm{A}+\mathrm{M}$ and $\mathrm{B}+\mathrm{M}$; table 1). For histology and Western blotting, see online supplementary material (for all online supplementary material, see www.karger.com/doi/10.1159/000341769).

Statistical Analysis

GraphPad Prism version 5.0 (GraphPad Software, La Jolla, Calif., USA) was used to analyze the data. Values are presented as means \pm SEM. Groups were compared using one-way and twoway analysis of variance (ANOVA), nonparametric Kruskal-Wallis tests and exact tests. Statistical significance was determined at $\mathrm{p}<0.05$. 
Table 1. Timetable of different histological and molecular experiments

\begin{tabular}{|c|c|c|c|c|c|c|c|c|c|c|c|c|c|}
\hline & $\mathrm{P} 1$ & $\mathrm{P} 2$ & P3 & $\mathrm{P} 4$ & P5 & P6 & P7 & P8 & P9 & P10 & $\mathrm{P} 11$ & $\mathrm{P} 12$ & P13 \\
\hline Model A ${ }^{1}$ & $\mathrm{X}$ & $\mathrm{X}$ & $\mathrm{X}$ & $¥$ & & & & & & & & & \\
\hline Model A+M ${ }^{2}$ & $\mathrm{XM}_{1}$ & $\mathrm{XM}_{1}$ & $\mathrm{XM}_{1}$ & $¥$ & & & & & & & & & \\
\hline Model B $^{3}$ & $\mathrm{X}$ & $\mathrm{X}$ & $\mathrm{X}$ & $\mathrm{X}$ & $\mathrm{X}$ & $¥$ & & & & & & & \\
\hline Model B+M ${ }^{4}$ & $\mathrm{XM}_{1}$ & $\mathrm{XM}_{1}$ & $\mathrm{XM}_{1}$ & $\mathrm{XM}_{1}$ & $\mathrm{XM}_{1}$ & $¥$ & & & & & & & \\
\hline Model C ${ }^{5}$ & & & & & & & & & & $\mathrm{X}$ & $\mathrm{X}$ & $\mathrm{X}$ & $¥$ \\
\hline Model D ${ }^{6}$ & & & $\mathrm{X}$ & & & & & & & & & & \\
\hline Model D+M ${ }^{7}$ & & & $\mathrm{XM}_{1}$ & & & & & & & & & & \\
\hline \multicolumn{6}{|c|}{$\begin{array}{l}\text { The schedules A-D were used. Different frequencies of in- } \\
\text { jections and variable postnatal ages were examined. X = Inter- } \\
\text { vention; } ¥=\text { perfusion; } \mathrm{XM}_{1}=\text { intervention with } 500 \mu \mathrm{g} \text { mor- } \\
\text { phine } / \mathrm{kg} \text {. } \\
{ }^{1} \text { Injection of } 5 \mu \mathrm{l} \text { formalin } 10 \% \text { (group } 1 \text { ), or injection of } 5 \mu \mathrm{l} \\
0.9 \% \text { saline (group } 2 \text { ), or controls (no injection, group } 3 \text { ) during } \\
\text { days P1-3, perfusion at day P4. }{ }^{2} \text { Animals of model A were pre- } \\
\text { treated with } 500 \mu \mathrm{g} \text { morphine } / \mathrm{kg} \text {. Controls received morphine } \\
\text { once a day without further interventions. }{ }^{3} \text { Injection of } 5 \mu \mathrm{l} \text { for- } \\
\text { malin } 10 \% \text { (group } 1 \text { ), or injection of } 5 \mu \mathrm{l} 0.9 \% \text { saline (group } 2 \text { ), or }\end{array}$} & \multicolumn{8}{|c|}{$\begin{array}{l}\text { controls (no injection, group } 3 \text { ) during days P1-5, perfusion at day } \\
\text { P6. }{ }^{4} \text { Animals of model B were pretreated with } 500 \mu \text { g morphine/ } \\
\text { kg. Controls received morphine once a day without further inter- } \\
\text { ventions. }{ }^{5} \text { Injection of } 5 \mu \text { l formalin } 10 \% \text { (group } 1 \text { ), or injection } \\
\text { of } 5 \mu \mathrm{l} 0.9 \% \text { saline (group } 2 \text { ), or controls (no injection, group } 3 \text { ) } \\
\text { during day P10-12, perfusion at day P13. }{ }^{6} \text { Injection of } 5 \mu l \text { for- } \\
\text { malin } 10 \% \text { and controls (no injection) on day P3, sacrificed after- } \\
\text { wards on the same day. }{ }^{7} 500 \mu g \text { morphine } / \mathrm{kg}+\text { injection of } 5 \mu \mathrm{l} \\
\text { formalin } 10 \% \text {, and controls, } 500 \mu \mathrm{g} \text { morphine } / \mathrm{kg} \text { on day P3, sac- } \\
\text { rificed afterwards on the same day. }\end{array}$} \\
\hline
\end{tabular}

\section{Results}

\section{Histology}

Model A

Animals received either formalin (group1, $n=7$ ) or saline (group 2, $\mathrm{n}=10$ ) in both hind and forepaws during days P1, P2 and P3 or no injections (control group 3, n = 9) (model A, see table 1). At day P4 animals were sacrificed and their brains were processed for histological staining as is illustrated in figure 1. Mean total apoptotic scores were 27,092, 13,044 and 7,625 degenerating cells/ $\mathrm{mm}^{3}$ for the formalin, saline and control group, respectively (fig. 2a). Significantly more apoptotic cells were counted in the formalin group and saline group compared to the control group (Mann-Whitney tests: $\mathrm{p}<$ 0.001 and $\mathrm{p}=0.006)$. Formalin-treated animals also showed higher scores than saline-treated animals ( $\mathrm{p}=$ 0.003). Most degenerated cells were found in the lamina II of both frontal and parietal cortex of the formalin and saline-treated animals (table 2).

\section{Model B}

In model B (table 1 ) experiments were prolonged until the 6th postnatal day (injections day P1-P5). At day P6 mean total apoptotic scores were 23,506, 25,862 and 10,092 degenerating cells $/ \mathrm{mm}^{3}$ for the formalin $(\mathrm{n}=8)$, saline $(\mathrm{n}=11)$ and control $(\mathrm{n}=8)$ groups, respectively (fig. 2b). Significantly more apoptotic cells were counted in the formalin and saline group compared to the control group (Mann-Whitney test: $\mathrm{p}<0.001$ ). No significant difference in the number of apoptotic cells were found between animals injected with formalin and saline ( $\mathrm{p}=$ 0.84). Most degenerated cells were found in the lamina II of both frontal and parietal cortex as well as in the cingulum of the formalin- and saline-treated animals (table 2).

\section{Effect of Postnatal Time/Age: Model C}

Animals were again divided into 3 groups and received either $5 \mu$ l formalin $10 \%(n=5)$ or $5 \mu$ l saline $(n=$ 4) in both hind and forepaws during days P10, P11 and P12 and were again compared to a control group $(\mathrm{n}=4)$ receiving no injections. At day P13, mean total apoptotic scores were comparable for the formalin, saline and control groups, 4,064, 3,759 and 3,162 degenerating cells/ $\mathrm{mm}^{3}$, respectively (fig. $2 \mathrm{c}$ ). Compared to the experiments in newborn animals (models A and B), the overall apoptotic scores, also in controls, were lower compared to those in newborn animals.

\section{Pretreatment with Morphine: Pain Models $A+M$ and $B+M$}

The effects of pretreatment with $500 \mu \mathrm{g} / \mathrm{kg}$ subcutaneous morphine before formalin or saline injections, as 

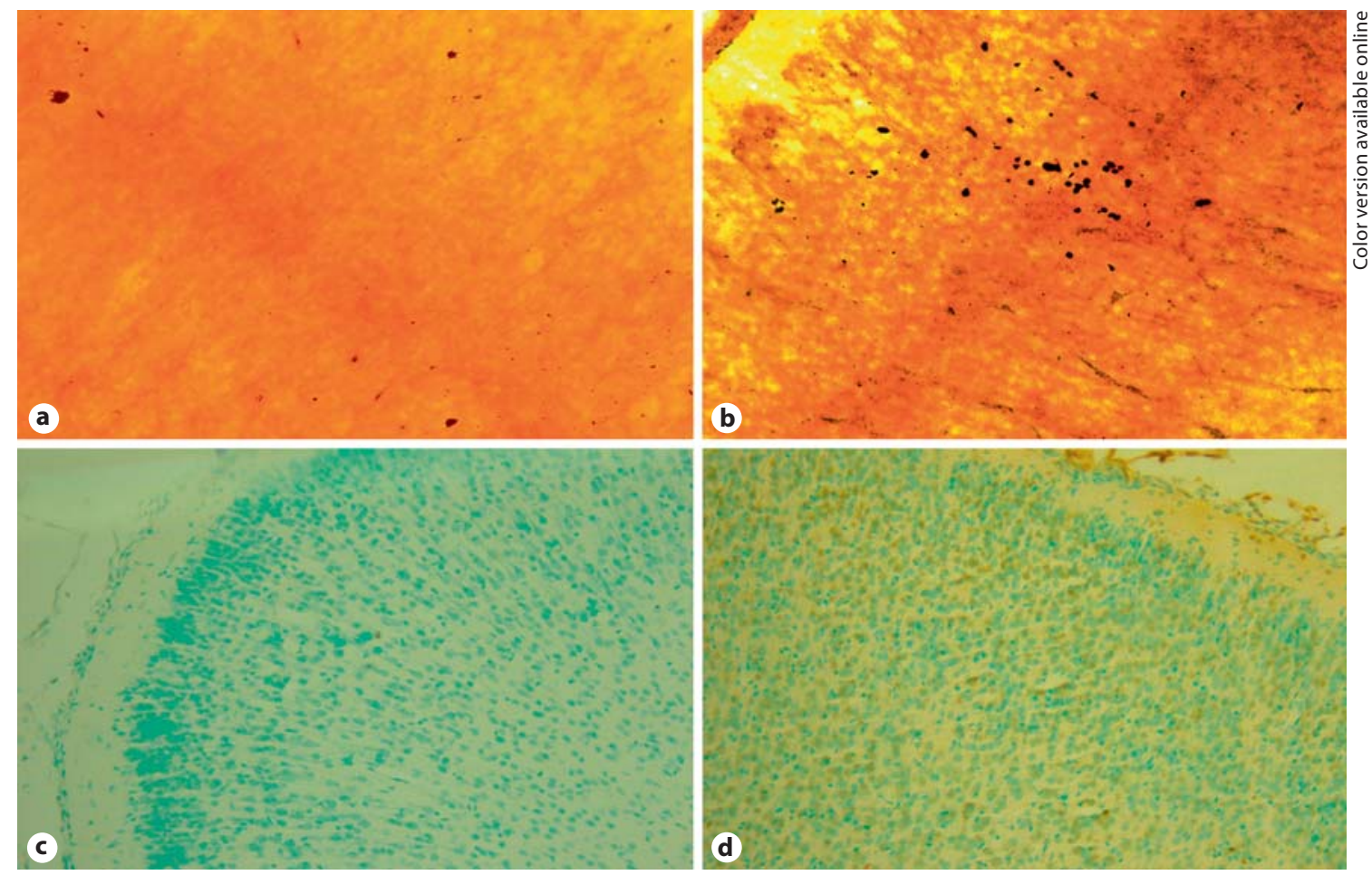

Fig. 1. de Olmos cupric silver staining $(\mathbf{a}, \mathbf{b})$ and TUNEL staining $(\mathbf{c}, \mathbf{d})$ of formalin-treated animals $(\mathbf{b}, \mathbf{d})$ compared to control animals $(\mathbf{a}, \mathbf{c})$. Formalin pain induces cell death in the immature rat brain. Neurodegenerative changes in the brains of $\mathrm{P} 4$ rats who were subjected to subcutaneous formalin injections for 3 days and sacrificed on P4. b In the injured frontal cortex from an animal subjected to formalin pain over 3 days, degenerated cells appear as small dark dots in $70-\mu \mathrm{m}$ silver-stained sections $(\times 40)$. d TUNEL staining performed in a $10-\mu \mathrm{m}$-thick cortical section confirms DNA fragmentation within degenerating cells $(\times 20)$.

Table 2. Number of apoptotic cells in different brain regions for models A and B

\begin{tabular}{|c|c|c|c|c|c|c|c|c|c|c|c|c|}
\hline & \multicolumn{6}{|c|}{ Model A } & \multicolumn{6}{|c|}{ Model B } \\
\hline & \multicolumn{2}{|c|}{ formalin $(n=7)$} & \multicolumn{2}{|c|}{ saline $(\mathrm{n}=10)$} & \multicolumn{2}{|c|}{ control $(\mathrm{n}=9)$} & \multicolumn{2}{|c|}{ formalin $(\mathrm{n}=8)$} & \multicolumn{2}{|c|}{ saline $(\mathrm{n}=11)$} & \multicolumn{2}{|c|}{ control $(\mathrm{n}=8)$} \\
\hline & mean & SEM & mean & SEM & mean & SEM & mean & SEM & mean & SEM & mean & SEM \\
\hline Frontal cortex (lamina II) & 10,796 & 2,375 & 4,143 & 696 & 1,651 & 334 & 8,357 & 868 & 8,662 & 535 & 2,929 & 514 \\
\hline Frontal cortex (lamina IV) & 192 & 35 & 163 & 29 & 95 & 28 & 257 & 49 & 244 & 39 & 193 & 53 \\
\hline Cingulate gyrus (lamina II) & 2,306 & 240 & 1,514 & 200 & 1,048 & 151 & 1,589 & 387 & 2,740 & 475 & 1,375 & 347 \\
\hline Cingulate gyrus (lamina IV) & 265 & 67 & 163 & 26 & 114 & 23 & 250 & 49 & 262 & 42 & 193 & 30 \\
\hline Nucleus caudatus & 106 & 25 & 114 & 24 & 64 & 19 & 425 & 114 & 353 & 76 & 211 & 60 \\
\hline Septum & 612 & 154 & 503 & 100 & 381 & 136 & 671 & 106 & 712 & 122 & 450 & 82 \\
\hline Parietal cortex (lamina II) & 7,612 & 932 & 3,586 & 851 & 2,587 & 741 & 7,143 & 941 & 8,454 & 700 & 2,303 & 261 \\
\hline Parietal cortex (lamina IV) & 155 & 14 & 132 & 21 & 83 & 35 & 193 & 30 & 270 & 40 & 189 & 53 \\
\hline Retrosplenial cortex (lamina II) & 1,857 & 584 & 914 & 117 & 476 & 48 & 982 & 186 & 792 & 116 & 518 & 97 \\
\hline Retrosplenial cortex (lamina IV) & 200 & 28 & 120 & 29 & 146 & 33 & 254 & 36 & 249 & 35 & 100 & 19 \\
\hline Medial thalamus & 359 & 45 & 229 & 37 & 156 & 41 & 639 & 87 & 439 & 45 & 204 & 34 \\
\hline Lateral thalamus & 555 & 205 & 406 & 100 & 219 & 54 & 550 & 99 & 481 & 89 & 368 & 98 \\
\hline Thalamus (V) & 216 & 55 & 209 & 50 & 108 & 28 & 282 & 43 & 473 & 50 & 279 & 73 \\
\hline Hypothalamus & 878 & 143 & 360 & 79 & 172 & 60 & 979 & 105 & 860 & 120 & 350 & 33 \\
\hline Subiculum & 555 & 85 & 260 & 56 & 111 & 22 & 507 & 67 & 465 & 78 & 175 & 37 \\
\hline Hippocampus (CA 1) & 253 & 106 & 154 & 27 & 143 & 33 & 329 & 42 & 231 & 47 & 111 & 16 \\
\hline Hippocampus (gyrus dentatus) & 188 & 76 & 137 & 22 & 102 & 31 & 98 & 29 & 174 & 22 & 150 & 28 \\
\hline
\end{tabular}




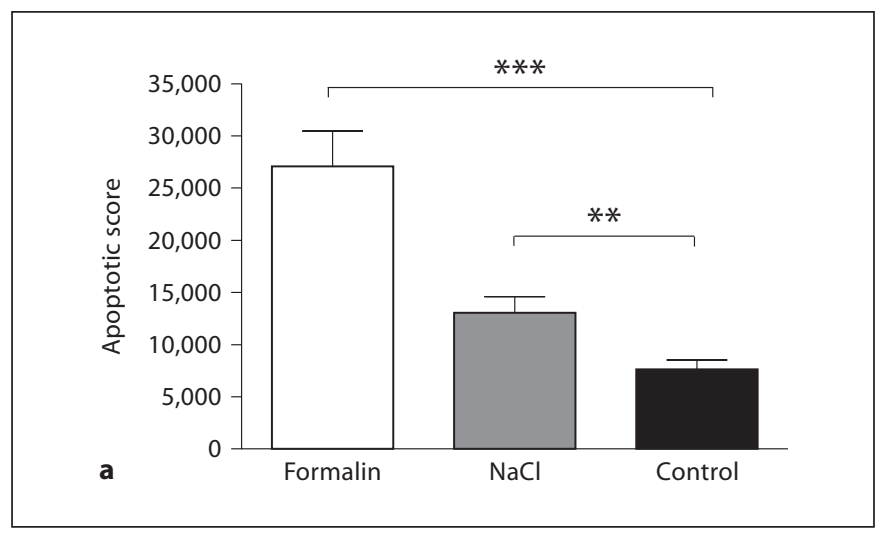

Fig. 2. Total apoptotic scores in the brain of animals at different ages. Model A (a) at day P4 after injections with formalin or saline at day P1 until day P3 compared to controls $(\mathrm{n}=7-10)$, model B (b) at day P6 after injections with formalin or saline at day P1 until day P5 compared to controls ( $\mathrm{n}=8-11$ per group), and model C (c) at day P13 after injections with formalin or saline at day P10 until day P12 compared to controls $(n=4-5) .{ }^{* *} \mathrm{p}=0.006$; *** $\mathrm{p}<0.001$; Mann-Whitney U nonparametric tests.

well as of receiving morphine therapy without injections, are shown in figure $3 \mathrm{a}$ (receiving injections on days $\mathrm{P} 1-$ $\mathrm{P} 3$, model $\mathrm{A}+\mathrm{M}$ ) and figure $3 \mathrm{~b}$ (injections on days $\mathrm{P} 1-\mathrm{P} 5$, model $\mathrm{B}+\mathrm{M})$.

For the animals in model $\mathrm{A}+\mathrm{M}$ (injected during $\mathrm{P} 1-$ P3; fig. 3a), the mean total apoptotic scores were 10,086, 9,971 and 11,657 degenerating cells $/ \mathrm{mm}^{3}$ for the animals treated with morphine and formalin, morphine and saline, and only morphine, respectively. Pretreatment with morphine reduced total apoptotic scores in the formalin group ( $\mathrm{p}=0.01)$, but not in the control and saline groups $(\mathrm{p}=0.065$ and $\mathrm{p}=0.71)$. Brains of animals in model $\mathrm{B}+\mathrm{M}$ (injected during P1-P5) showed mean total apoptotic scores of 17,371, 19,942 and 11,908 degenerating cells/ $\mathrm{mm}^{3}$ for the animals treated with morphine and formalin, morphine and saline, and morphine alone, respectively. In this model, morphine significantly reduced the number of degenerating cells only in animals receiving morphine prior to saline injections.

The results of the cupric silver staining were acknowledged by TUNEL-staining (fig. 1).
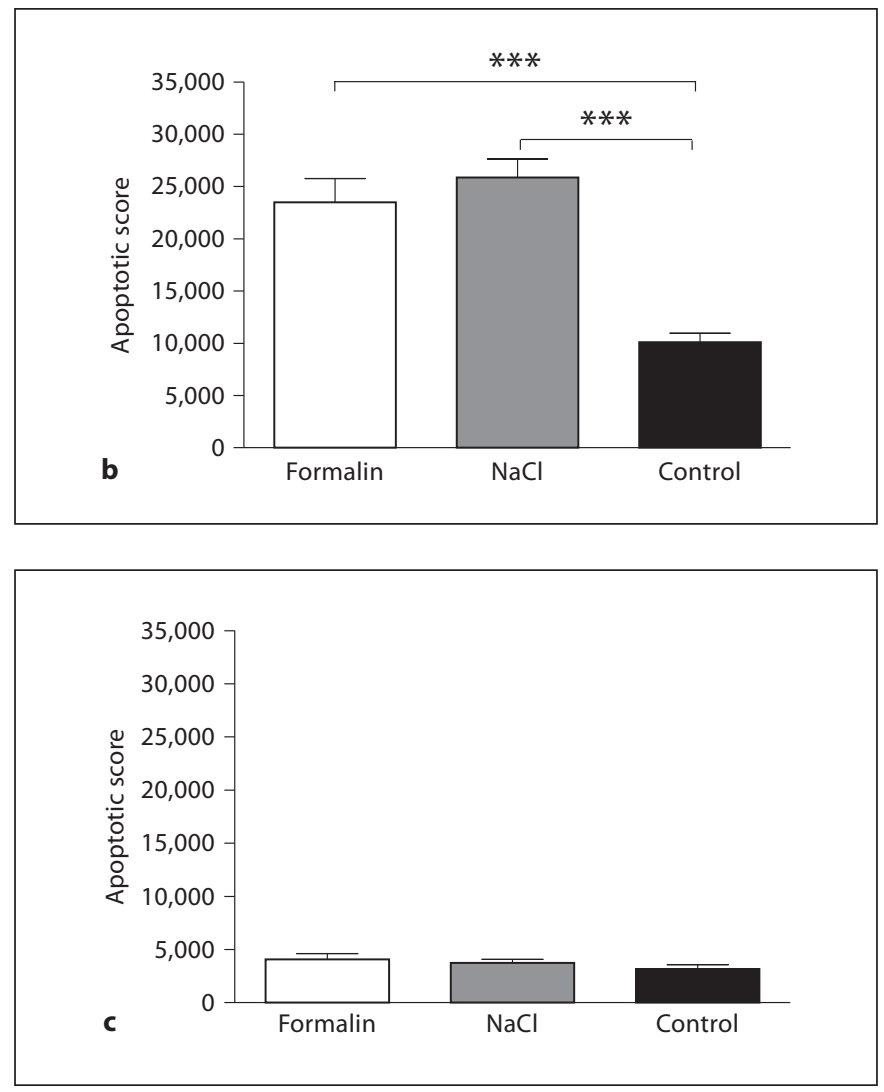

\section{Protein Biochemistry}

PKCvarepsilon and DCX protein expressions were studied in the cortex and thalamus (table 1). After formalin injections on day 3 (model D), PKCvarepsilon was upregulated in cortices after $2 \mathrm{~h}$. Prior subcutaneous injection of morphine (model $\mathrm{D}+\mathrm{M}$ ) resulted in a significant reduction of cortical PKCvarepsilon concentration compared to the formalin group (fig. 4).

DCX expression was only influenced in the thalamus where protein concentrations were increased by painful stimuli at 2 and $6 \mathrm{~h}$ after formalin injections. Again, morphine injections prevented the rise in DCX concentration in the thalamus (fig. 4).

\section{Discussion}

Both neonatal pain and opioid exposure are important factors that may influence central nervous system pathways and cell survival. In the current study we show cell death in neonatal rat brains subjected to mild and severe pain. This damage probably consists of neuronal apopto-

Neonatology 2013;103:35-43 


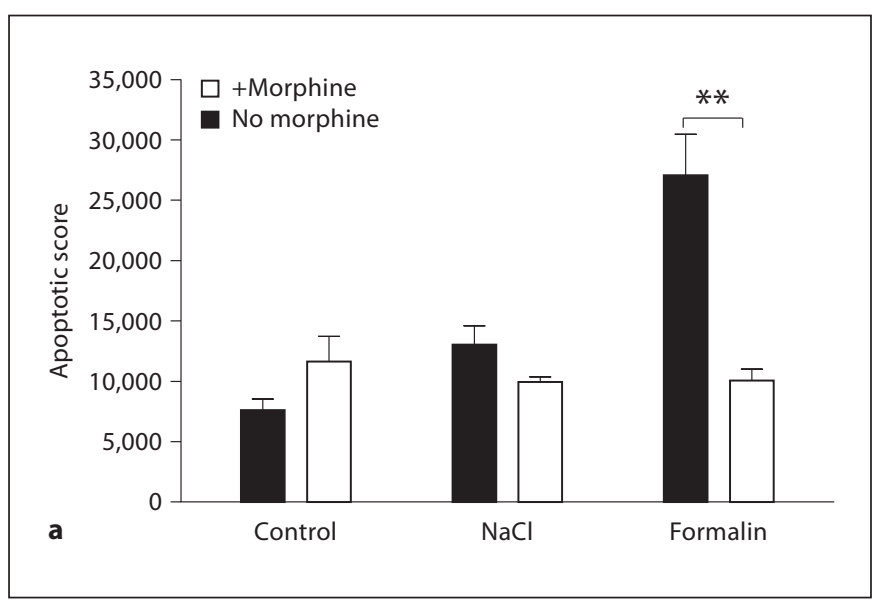

Fig. 3. The effect of preemptive morphine in saline- and formalintreated animals compared to controls on apoptotic scores. a Morphine injection reduces the amount of degenerated neurons induced by formalin pain at $\mathrm{P} 4($ model $\mathrm{A}+\mathrm{M})$. b This morphine effect after 5 days of painful injections (P1-P5) is less impressive

sis as shown by TUNEL and de Olmos cupric silver staining [20]. Severe pain also altered the expression of the neurodevelopmentally important proteins PKCvarepsilon and DCX. Comparable to our results, Juul et al. [17] showed an effect between the severity of stress and the amount of gene expression in the neonatal murine hippocampus. This indicates a dose-dependant relationship between distress and the neuronal damage.

Interestingly, morphine pretreatment was only related to decreased neurological damage in some of the experiments. Morphine seems to protect against cell degeneration from severe 3 days repeated formalin pain and 5 days repetitive mild pain from saline injections. Morphine could not significantly decrease severe formalin pain after 5 days. Morphine might protect the brain up to a certain limit. Previous animal studies also showed interactive effects between morphine and pain [14-17]. Morphine seems to downregulate specific stress-related changes in gene expression that protect the cell against apoptosis [13]. In older human infants, the beneficial effect of anesthesia for surgery was established decades ago [21]. There is, however, no human clinical evidence of long-term beneficial effects of morphine administered for daily neonatal care. In fact, the scant research in human preterm neonates suggests that continuous preemptive analgesia may have adverse effects [5, 9-11]. Opioids seem to have different effects in the presence or absence of pain. In rodent studies, where animals were known to be in pain, morphine prevented some changes to the neo-

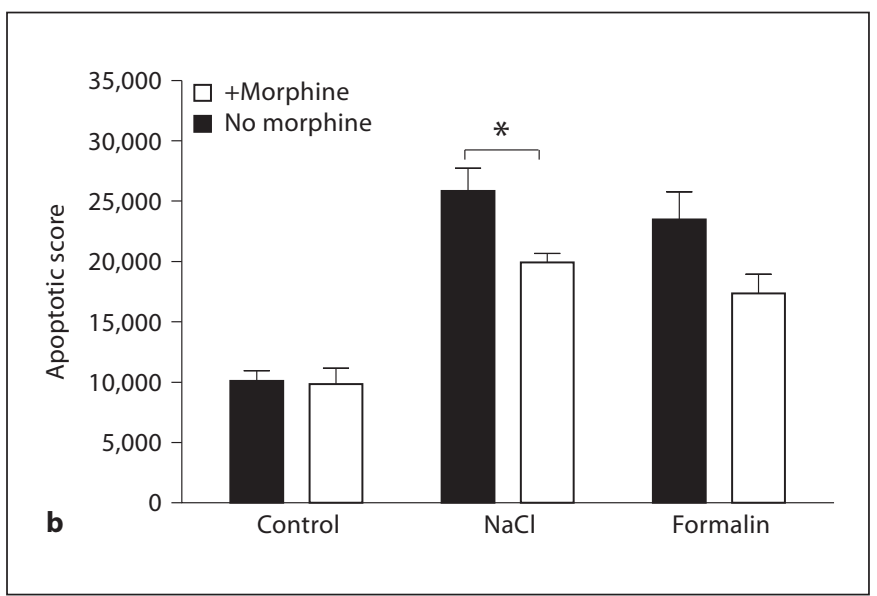

and not even significant for formalin pain-treated animals (model $\mathrm{B}+\mathrm{M})$. The white bars represent animals who received additional morphine treatment. ${ }^{*} \mathrm{p}=0.02$; ${ }^{*} \mathrm{p}=0.01$; two-way ANOVA/Mann-Whitney test $(n=5)$.

natal nociceptive system caused by pain $[14,16]$, while in the absence of pain, opioids have been found to be neurotoxic and can impair cognitive and behavioral development $[22,23]$.

Opioids and endorphins probably play an important role in modulation and regulation of neuronal differentiation and survival. PKCvarepsilon participates in the neuroprotective effects of morphine [24], whereas PKCvarepsilon overexpression increases NMDA-receptor activity leading to excitotoxic cell death [25]. In our study, cortical PKCvarepsilon was acutely increased by painful stimuli and then dropped to the initial level. PKCvarepsilon expression was lower in the morphinetreated animals. DCX showed a steep rise in concentration in the thalamus region after severe prolonged pain. This DCX overexpression may reflect diffuse migration and an abnormal differentiation of neuroblasts [19, 26], but may also be a protective reaction as a response to pain-related degeneration of neurons [27]. Morphine pretreatment again reduced the DCX levels. This supports the potential protective role of preemptive analgesia in newborn infants. However, further research is needed to elucidate the underlying mechanisms.

Our study has some important limitations. It is difficult to translate the animal data to the human preterm neonate. Pain did not increase neurodegeneration in rats at older ages, suggesting an age-dependent effect. Although the brain of newborn rats is probably comparable to premature born humans, the period of brain spurt oc- 

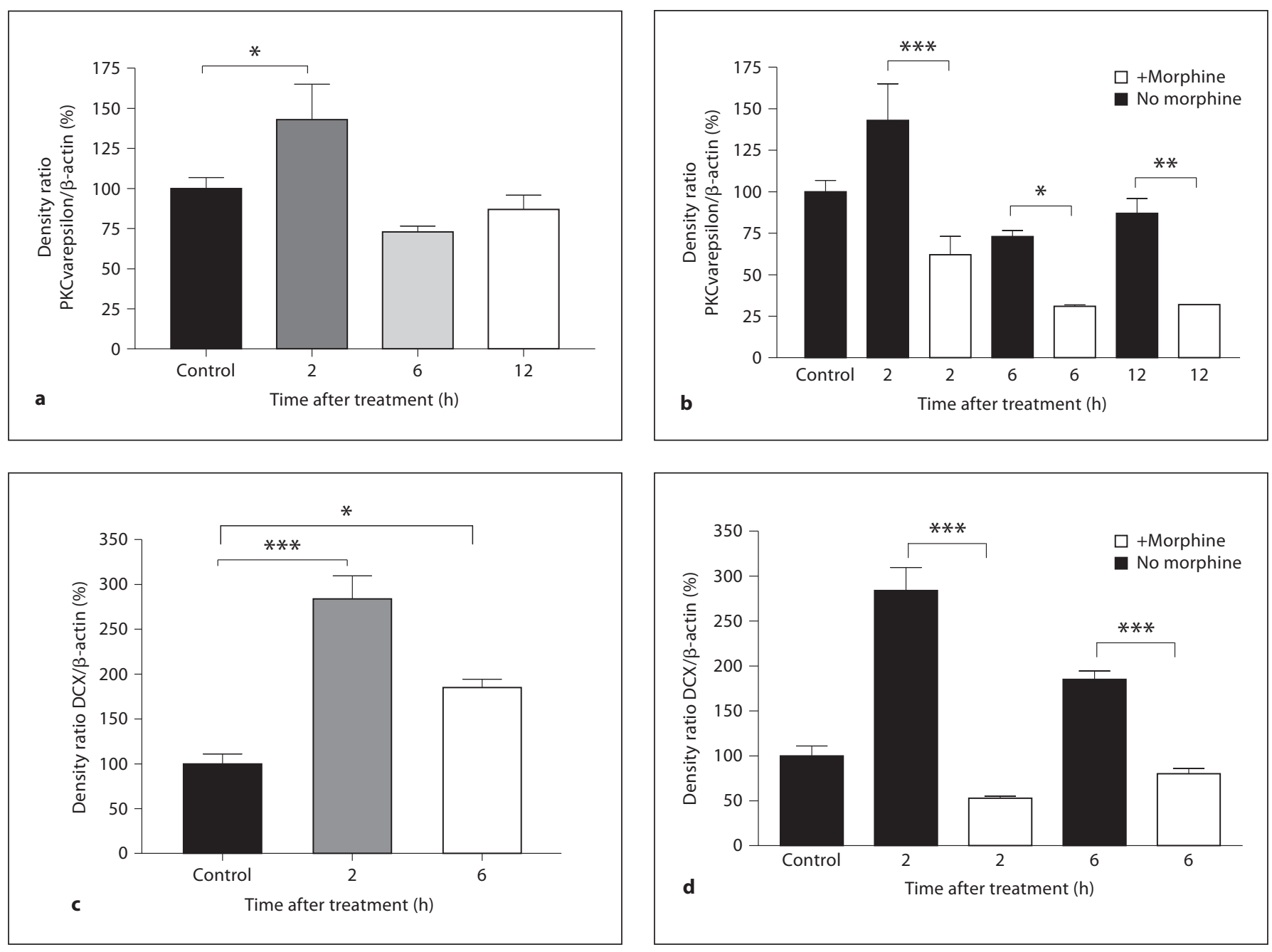

Fig. 4. PKCvarepsilon and DCX protein expression levels. a Formalin injection leads to a quick rise in PKCvarepsilon concentration after $2 \mathrm{~h}$ in the cortex of neonatal rats (model D). b The injection of morphine prior to the injection of formalin results in a reduction of $\mathrm{PKCvarepsilon} \mathrm{concentration} \mathrm{in} \mathrm{the} \mathrm{neonatal} \mathrm{rat} \mathrm{cor-}$ tex after 2, 6 and $12 \mathrm{~h}$ (model D). c Thalamic DCX levels in formalin-treated neonatal rats compared to controls. DCX is influenced by painful events. The formalin pain leads to a steep rise

after $2 \mathrm{~h}$, and is still elevated after $6 \mathrm{~h}$ compared to control animals. d Effect of morphine treatment on DCX in neonatal rats after formalin-induced pain. As PKCvarepsilon, DCX protein expression is lowered due to morphine exposure prior to formalin injections. b, d The white bars represent animals who received additional morphine treatment. ${ }^{*} \mathrm{p}<0.05$; ${ }^{* *} \mathrm{p}<0.01$; ${ }^{* * *} \mathrm{p}<$ 0.001 ; one-way ANOVA ( $n=5$ per group).

curs in different species at different times relative to birth [28].

Formalin-induced pain is a well-worked out nociceptive model in the infant rodent [14]. Unfortunately, we did not measure the amount of pain and cannot discriminate between pain, stress and inflammation. Formalin injections led to a clear nociceptive reaction. After repetitive injections, a severe ongoing inflammation of the paws was seen. After prolonged injections (model B), morphine did not decrease the apoptotic scores any more.

The formalin model simulates ongoing severe distress and probably overestimates the amount of distress related to routine neonatal intensive care unit treatment [29].

Repetitive saline injections probably are a more suitable model for human neonates receiving repetitive painful procedures. Prolonged use of repetitive saline injections showed an enormous potential impact on the developing brain. As an isotonic, sodium chloride solution is not expected to have any toxic effects; neuronal degeneration is caused by repeated pain induced by the injec- 
tions itself or by the inflammatory response to the injections. Consistent with the only human study of neonatal pain in relation to brain microstructure development in preterm humans [3], this indicates the extreme vulnerability of the premature brain and the potential danger of frequently repeated pain and stressful stimuli in premature neonates.

Even today, neonatal intensive care treatment is related to inescapable frequent painful procedures and distress, often without analgesic pharmacological therapy $[1,2,29]$. Clinical trials have not shown beneficial effects, but effects such as hypotension and prolonged ventilation of routinely used morphine during artificial ventilation $[5,9-11]$. Therefore, opioid treatment is not standard of care nowadays in ventilated newborns. Current neonatal pain treatment focuses on individualized pharmacological and nonpharmacological approaches. Our data provides evidence that morphine has a neuroprotective effect when given prior to painful stimuli and in that way encourages the clinical use of opioids if a newborn is known to suffer from pain. As opioids seem to have different effects in the presence or absence of pain, one of the major clinical challenges is to identify when a preterm infant is actually in pain. It is of great importance for both clinicians and researchers to further explore this important area of research.

\section{Acknowledgement}

This study was financially supported by grants from the Netherlands Organisation of Scientific Research, the Trust Funds of the Erasmus University Rotterdam and the Sonnenfeld-Stiftung, Berlin.

\section{Disclosure Statement}

There are no conflicts of interest stated by the authors.

\section{References}

1 Carbajal R, Rousset A, Danan C, Coquery S, Nolent P, Ducrocq S, Saizou C, Lapillonne A, Granier M, Durand P, Lenclen R, Coursol A, Hubert P, de Saint BL, Boelle PY, Annequin D, Cimerman P, Anand KJ, Breart G: Epidemiology and treatment of painful procedures in neonates in intensive care units. JAMA 2008;300:60-70.

-2 Simons SHP, van Dijk M, Anand KJS, Roofthooft D, van Lingen RA, Tibboel D: Do we still hurt newborn babies? A prospective study of procedural pain and analgesia in neonates. Arch Pediatr Adolesc Med 2003;157: 1058-1064.

3 Brummelte S, Grunau RE, Chau V, Poskitt KJ, Brant R, Vinall J, Gover A, Synnes AR, Miller SP: Procedural pain and brain development in premature newborns. Ann Neurol 2012;71:385-396.

4 Smith GC, Gutovich J, Smyser C, Pineda R, Newnham C, Tjoeng TH, Vavasseur C, Wallendorf M, Neil J, Inder T: Neonatal intensive care unit stress is associated with brain development in preterm infants. Ann Neurol 2011;70:541-549.

$\checkmark 5$ de Graaf J, van Lingen RA, Simons SH, Anand KJ, Duivenvoorden HJ, Weisglas-Kuperus N, Roofthooft DW, Groot Jebbink LJ, Veenstra RR, Tibboel D, van Dijk M: Longterm effects of routine morphine infusion in mechanically ventilated neonates on children's functioning: five-year follow-up of a randomized controlled trial. Pain 2011;152: 1391-1397.
-6 Grunau RE, Whitfield MF, Petrie-Thomas J, Synnes AR, Cepeda IL, Keidar A, Rogers M, Mackay M, Hubber-Richard P, Johannesen D: Neonatal pain, parenting stress and interaction, in relation to cognitive and motor development at 8 and 18 months in preterm infants. Pain 2009; 143:138-146.

-7 Hermann C, Hohmeister J, Demirakca S, Zohsel K, Flor H: Long-term alteration of pain sensitivity in school-aged children with early pain experiences. Pain 2006;125:278-285.

$>8$ Davidson AJ: Anesthesia and neurotoxicity to the developing brain: the clinical relevance. Paediatr Anaesth 2011;21:716-721.

$\checkmark 9$ Anand KJ, Hall RW, Desai N, Shephard B, Bergqvist LL, Young TE, Boyle EM, Carbajal R, Bhutani VK, Moore MB, Kronsberg SS Barton BA: Effects of morphine analgesia in ventilated preterm neonates: primary outcomes from the NEOPAIN randomised trial Lancet 2004;363:1673-1682.

10 Bellu R, de Waal KA, Zanini R: Opioids for neonates receiving mechanical ventilation. Cochrane Database Syst Rev 2008; 1:CD004212.

11 Simons SHP, van Dijk M, van Lingen RA, Roofthooft DWA, Duivenvoorden HJ, Jongeneel N, Bunkers C, Smink E, Anand KJS, van den Anker JN, Tibboel D: Routine morphine infusion in preterm neonates who received ventilatory support: a randomized controlled trial. JAMA 2003;290:2419-2427.
12 Bittigau P, Sifringer M, Genz K, Reith E, Pospischil D, Govindarajalu S, Dzietko M, Pesditschek S, Mai I, Dikranian K, Olney JW, Ikonomidou C: Antiepileptic drugs and apoptotic neurodegeneration in the developing brain. Proc Natl Acad Sci USA 2002;99: 15089-15094.

13 Zhang Y, Chen Q, Yu LC: Morphine: a protective or destructive role in neurons? Neuroscientist 2008;14:561-570.

14 Bhutta AT, Rovnaghi C, Simpson PM, Gossett JM, Scalzo FM, Anand KJS: Interactions of inflammatory pain and morphine in infant rats: long-term behavioral effects. Physiol Behav 2001;73:51-58.

15 Boasen JF, McPherson RJ, Hays SL, Juul SE, Gleason CA: Neonatal stress or morphine treatment alters adult mouse conditioned place preference. Neonatology 2009;95:230239.

-16 Laprairie JL, Johns ME, Murphy AZ: Preemptive morphine analgesia attenuates the long-term consequences of neonatal inflammation in male and female rats. Pediatr Res 2008;64:625-630.

17 Juul SE, Beyer RP, Bammler TK, Farin FM, Gleason CA: Effects of neonatal stress and morphine on murine hippocampal gene expression. Pediatr Res 2011;69:285-292.

18 Scott HL, Braud S, Bannister NJ, Isaac JT: Synaptic strength at the thalamocortical input to layer IV neonatal barrel cortex is regulated by protein kinase C. Neuropharmacology 2007;52:185-192. 
-19 Francis F, Koulakoff A, Boucher D, Chafey P, Schaar B, Vinet MC, Friocourt G, McDonnell N, Reiner O, Kahn A, McConnell SK, Berwald-Netter Y, Denoulet P, Chelly J: Doublecortin is a developmentally regulated, microtubule-associated protein expressed in migrating and differentiating neurons. Neuron 1999;23:247-256.

20 Bittigau P, Sifringer M, Pohl D, Stadthaus D, Ishimaru M, Shimizu H, Ikeda M, Lang D, Speer A, Olney JW, Ikonomidou C: Apoptotic neurodegeneration following trauma is markedly enhanced in the immature brain. Ann Neurol 1999;45:724-735.

-21 Anand KJS, Hickey PR: Halothane-morphine compared with high-dose sufentanil for anesthesia and postoperative analgesia in neonatal cardiac surgery. N Engl J Med 1992; 326:1-9.
22 Ma MX, Chen YM, He J, Zeng T, Wang JH: Effects of morphine and its withdrawal on Y-maze spatial recognition memory in mice. Neuroscience 2007;147:1059-1065.

23 McPherson RJ, Gleason C, Mascher-Denen M, Chan M, Kellert B, Juul SE: A new model of neonatal stress which produces lasting neurobehavioral effects in adult rats. Neonatology 2007;92:33-41.

24 Fanjun M, Junfa L, Bingxi Z, Fang J: nPKCepsilon and NMDA receptors participate in neuroprotection induced by morphine pretreatment. J Neurosurg Anesthesiol 2006;18: 119-124.

25 Chen L, Huang LY: Protein kinase C reduces $\mathrm{Mg} 2+$ block of NMDA-receptor channels as a mechanism of modulation. Nature 1992; 356:521-523.
26 Gleeson JG, Lin PT, Flanagan LA, Walsh CA: Doublecortin is a microtubule-associated protein and is expressed widely by migrating neurons. Neuron 1999;23:257-271.

27 Chiaretti A, Barone G, Riccardi R, Antonelli A, Pezzotti P, Genovese O, Tortorolo L, Conti G: NGF, DCX, and NSE upregulation correlates with severity and outcome of head trauma in children. Neurology 2009;72:609616.

28 Clancy B, Finlay BL, Darlington RB, Anand KJ: Extrapolating brain development from experimental species to humans. Neurotoxicology 2007;28:931-937.

29 Johnston C, Barrington KJ, Taddio A, Carbajal R, Filion F: Pain in Canadian NICUs: have we improved over the past 12 years? Clin J Pain 2011;27:225-232. 